\section{CPPU Influences Fruit Quality, Fruit Set, Return Bloom, and Preharvest Drop of Apples}

\author{
Eric A. Curry \\ Agricultural Research Service, U.S. Department of Agriculture, Tree Fruit \\ Research Laboratory, 1104 North Western Avenue, Wenatchee, WA 98801
}

Duane W. Greene

Department of Plant and Soil Sciences, University Of Massachusetts, Amherst, MA 01003

Additional index words. cytokinins, growth regulator, Malus domestica

Abstract. CPPU was applied to whole spur 'Delicious' apple (Malus domestica Borkh.) trees in central Washington at $0,6.25,12.5,25$, or $50 \mathrm{mg} \cdot$ liter- $^{-}$at full bloom (FB) or FB plus 2 weeks. At both application times, the flesh firmness of treated fruit linearly increased with increasing concentration. CPPU applied at $0,5,10,15$, or $20 \mathrm{mg}^{-1 i t e r}{ }^{-1}$ to spur 'Delicious' trees in Massachusetts at king bloom resulted in a linear increase in flesh firmness at harvest and following 28 weeks in air storage at 0C. CPPU did not affect the incidence of senescent breakdown, decay, or cork spot. Fruit length : diameter (L/D) ratios generally increased at all doses. Fruit weight was not influenced at either location. All CPPU concentrations reduced return bloom on 'Delicious' apples in Massachusetts in 1989. Of the 10, 20, or $40 \mathrm{mg} \cdot \mathrm{liter}^{-1}$ treatments for 'Empire' apples, only CPPU at $40 \mathrm{mg} \cdot \mathrm{liter}^{-1}$ reduced return bloom. CPPU applied to 'Empire' apples in Massachusetts did not effect fruit set, soluble solids concentration, L/D, or firmness; however, fruit weight increased linearly with concentration. CPPU applied at $100 \mathrm{mg}^{-1 i t e r}{ }^{-1}$ retarded preharvest fruit drop of 'Early McIntosh' in Massachusetts for $\approx 7$ days but was not as effective as NAA at 20 mg-liter ${ }^{-1}$. In a larger semicommercial trial, 'Delicious' fruit treated with CPPU at 5,10,

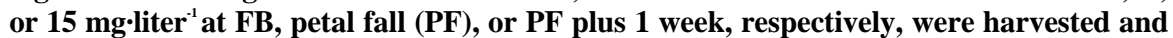
graded over a commercial packing line. Malformities caused by CPPU at the highest doses reduced packout, although all CPPU application rates reduced the percent fruit culled due to poor color. CPPU increased packed fruit size, since the size of fruit $(64 \mathrm{~mm}$ in diameter) in the $>150$-fruit/box size decreased, while the size of fruit $(72 \mathrm{~mm}$ in diameter) in the 100and 130-fruit/box sizes increased. Treated fruit stored for 7 months at $1 \mathrm{C}$ were firmer than nontreated controls. Chemical names used: N-(2-chloro-4-pyridyl)- $N^{\prime}$-phenylurea (CPPU); 1 naphthalene-acetic acid (NAA).

Diphenylurea, a synthetic cytokinin, has shown considerable cytokinin-like activity (Shantz and Steward, 1955). Bruce et al. (1965) showed that substituting diphenylurea for zeatin (a true cytokinin) resulted in compounds with a wide spectrum of activity similar to that of zeatin compounds. Several substituted phenylurea compounds, including CPPU (also known as fenclopyr, KT-30, 4-PU, and CN11-3 183; SKW Trostberg AG, Trostberg, Germany), have been shown to have a high cytokinin activity by the tobacco callus proliferation assay (Okamoto et al., 1981; Takahashi et al., 1978; Thomas and Katterman, 1986). Kurosaki et al. (198 1) showed that CPPU has

Received for publication 19 Mar. 1992. Accepted for publication 10 Sept. 1992. Mention of a trademark, warranty, proprietary product, or vendor does not constitute a guarantee by the U.S. Dept. of Agriculture and does not imply its approval to the exclusion of other products or vendors that also may be suitable. The cost of publishing this paper was defrayed in part by the payment of page charges. Under postal regulations, this paper therefore must be hereby marked advertisement solely to indicate this fact.
Washington. The experimental site was a uniform block of 9-year-old 'Oregon Spur Delicious'/MM.111 trees located in central Washington. Trees were planted in a light sandy loam soil and irrigated by a permanent set of under-tree sprinklers. At the balloon stage of flower development, 66 trees were selected and randomly assigned to one of seven chemical treatments to be applied at full bloom (FB) or FB plus 2 weeks for a total of 14 treatments. Included in each treatment was a nonionic surfactant, Regulaid (Kalo Laboratories, Kansas City, MO.), at $0.125 \%$. The treatments were (in mg.liter ${ }^{-1}$ ) as follows: 1) nontreated, Regulaid only; 2) CPPU, 6.25; 3) CPPU, 12.5; 4) CPPU, 25; 5) CPPU, 50; 6) CPPU, 12.5, plus gibberellic acid $\left(\mathrm{GA}_{+t 7}\right), 12.5$; and 7) 6-benzyladenine (BA) plus GA,+, [Promalin (Abbott Laboratories, North Chicago, Ill.)], 25. Application was stopped before the drip point to simulate a spray volume of $\approx 306$ liters $\cdot$ ha $^{-1}$. There were three whole-tree replications per treatment. The first treatments were applied on 5 May 1986. At commercial harvest in September, 40 fruit from each tree were harvested, beginning at the end of the limbs selected from the north side of the tree. In the laboratory, all fruit were weighed and L/ D was measured. Flesh firmness was determined on opposite sides of each apple using an electronic penetrometer with a $10-\mathrm{mm}$ probe (model LPT-1; Lake City Electronics, Kelowna, B.C.). Soluble solids concentration (SSC) was determined for each apple using a hand refractometer, and total acidity was quantified by titrating a $10-\mathrm{ml}$ juice sample to $\mathrm{pH} 8.2$.

Effect of CPPU on spur 'Delicious'/M.26 in Massachusetts. A block of 8-year-old spur 'Delicious'/M.26 at the Univ. of Massachusetts Horticultural Research Center (UMHRC), Belchertown, was grouped into six uniform blocks of six trees each. When king blossoms opened, one tree in each block was treated to the drip point with CPPU at $0,5,10,15$, or 20 mg.liter ${ }^{-1}$ plus $0.05 \%$ Buffer-X. One tree in each block was sprayed with Promalin at 25 mg-liter ${ }^{-1}$. Treatments were replicated six times as single-tree treatments. All trees were thinned with NAA at $3 \mathrm{mg} \cdot$ liter $^{-1}$ plus 1-naphthalenyl methylcarbamate (carbaryl) at $600 \mathrm{mg} \cdot$ liter $^{-1}$. At the commercial harvest date, 30 fruit were selected at random from the periphery of the tree. All harvested fruit were weighed, L/D was measured, and the seeds were counted. Ten fruit representative of a sample were selected, and flesh firmness was determined on two sides of each fruit using an Effegi penetrometer (Effegi, Alfonsine, Italy). SSC was measured in juice collected from the pressure test using a hand refractometer. Twenty kilograms of fruit per replication also were placed in air storage at $0 \mathrm{C}$ for 28 weeks. When the fruit were removed from storage, flesh firmness was determined as described for harvest evaluation. Fruit were allowed to remain at 20C for 21 days, after which 60 fruit were evaluated for storage disorders. The following spring, two $\approx 3.8$-cm-diameter limbs on each tree were tagged. When blossoms were in the pink stage, all blossom clusters on tagged limbs were counted. 
Effect of CPPU on 'Empire' apples in Massachusetts. Five uniform limbs on each of seven mature 'Empire'/MM.106 trees at UMHRC were tagged before bloom and all blossom clusters counted. On 4 June, 17 days after FB, $0.05 \%$ Buffer-X plus CPPU was applied to the drip point at $0,10,20$, or 40 mg.liter ${ }^{-1}$ to one limb on each tree. At the end of June drop, fruit on the tagged limbs were counted. At the commercial harvest, 40 apples were harvested from each limb. Fruit weight, shape, and quality were determined as described for spur 'Delicious' in Massachusetts.

Effect of CPPU on preharvest drop of 'Early McIntosh' in Massachusetts. Mature 'Early McIntosh'/M.7 growing at UMHRC were used in this study. Four limbs, 3.8 to 4.8 $\mathrm{cm}$ in diameter, per tree were selected, tagged, and all fruit counted on 1 Aug. On 2 Aug., two limbs per tree were sprayed to the drip point with CPPU at 50 or $100 \mathrm{mg} \cdot$ liter $^{-1}$, and a third limb was sprayed with NAA at $20 \mathrm{mg} \cdot$ liter $^{-1}$. All treatments included $0.05 \%$ Buffer-X. The fourth limb on each tree was not sprayed and served as the control. All fruit persisting through the same season on the tagged limbs were counted periodically, and the percent drop calculated was based on the number of fruit present on 1 Aug.

Commercial grading of 'Hi-Early Delicious' treated with CPPU in Washington. Blocks of 0.4 ha were selected from a uniform 16-ha block of 20-year-old 'Hi-Early Delicious'/seedling trees in central Washington. The soil was a sandy loam, and trees were irrigated with overhead sprinklers. Trees were treated in Spring 1989 and treatments consisted of the following: 1) nontreated control, Regulaid only; 2) Promalin at $25 \mathrm{mg} \cdot \mathrm{liter}^{-1}$ applied at FB; 3) CPPU at $5 \mathrm{mg} \cdot$ liter $^{-1}$ applied at FB; 4) CPPU at $10 \mathrm{mg} \cdot$ liter $^{-1}$ applied at petal fall (PF); and 5) CPPU at $15 \mathrm{mg} \cdot$ liter $^{-1}$ applied at PF plus 1 week. All treatments were applied to 0.4 ha of fruit with a commercial airblast sprayer. Treatments 2 and 3 were applied at a spray volume of $\approx 153$ liters.ha ${ }^{-1}$, and treatments 4 and 5 at 306 liters.ha ${ }^{-1}$ to compensate for increased foliage in the canopy. Treatments were applied at $\approx 0600$ HR in dry weather with ambient temperature between 6 and 10C. All other commercial practices were the same for the whole block. The fruit were picked at normal commercial harvest and the bins tagged according to treatment. Fruit were placed in air storage at $0 \mathrm{C}$ until they were run through a commercial packing line on 16 Dec. 1989. Cull types were determined by examining 100 fruit from the cull bin after fruit from each treatment were packed. Also, one box $(20 \mathrm{~kg})$ of size 100 fruit ( $72 \mathrm{~mm}$ in diameter) from each of the CPPU treatments was kept in air storage at 0C. In April, 80 fruit per treatment were placed in a room at $20 \mathrm{C}$ for 7 days before firmness testing, as previously described.

In Spring 1990, 20 limbs were selected randomly from trees in each block, their circumferences measured, and all blossom clusters counted.

Data from all replicated experiments were analyzed as a one-way analysis of variance in a randomized complete-block or completely randomized design. Means were separated by regression using SAS's General Linear Model procedure (SAS Institute, 1985) or by Duncan's multiple range test.

The large semicommercial trial was not a replicated experiment, but was designed to simulate commercial treatments. We fully realize the shortcomings of the data gathered from this endeavor and the interpretations derived therefrom. However, the data were included in an effort to substantiate results from the smaller replicated studies.

Fruit quality of 'Oregon Spur Delicious' in Washington. CPPU applied at FB or 2 weeks later did not affect fruit weight, SSC, or fruit acidity (Table 1). The optimum CPPU concentration for increasing fruit L/D was 12.5 to $25.0 \mathrm{mg} \cdot$ liter $^{-1}$. At $50 \mathrm{mg} \cdot$ liter $^{-1}$, CPPU may have increased fruit diameter more than fruit length (data not shown). This difference resulted in a significant quadratic regression. Flesh firmness increased linearly with concentrations at both application times. Adding $\mathrm{GA},+$, to CPPU had little influence other than slightly reducing titratable acidity compared with that of fruit treated with CPPU alone at FB plus 2 weeks.

Effect of CPPU on spur 'Delicious'/M.26in Massachusetts. CPPU applied to 'Delicious' in Massachusetts did not affect fruit weight, SSC, or seed count (data not shown). L/D increased in all treatments compared with the

Table 1. Effect of CPPU and Promalin applied at full bloom or at full bloom plus 2 weeks on fruit characteristics of 'Oregon Spur Delicious'/MM.111 apples in Washington.

\begin{tabular}{|c|c|c|c|c|c|}
\hline $\begin{array}{l}\text { Compound and } \\
\text { concn (mg.liter-1) }\end{array}$ & $\begin{array}{l}\text { Fruit } \\
\text { wt (g) }\end{array}$ & $\begin{array}{c}\text { Flesh } \\
\text { firmness (N) }\end{array}$ & $\begin{array}{l}\text { Soluble } \\
\text { solids } \\
\text { concn }(\%)\end{array}$ & Acidity $(\%)$ & $\mathrm{L} / \mathrm{D}^{2}$ \\
\hline \multirow{2}{*}{\multicolumn{6}{|c|}{ Full bloom }} \\
\hline & & & & & \\
\hline 1) 0 & 219 & 62 & 13.2 & 0.171 & 1.03 \\
\hline 2) 6.25 & 214 & 65 & 13.3 & 0.170 & 1.05 \\
\hline 3) 12.5 & 223 & 67 & 13.7 & 0.172 & 1.08 \\
\hline 4) 25.0 & 227 & 67 & 13.6 & 0.158 & 1.08 \\
\hline 5) 50.0 & 216 & 73 & 13.8 & 0.161 & 1.05 \\
\hline 6) $+\mathrm{GA}_{4+7}$, both 12.5 & 240 & 67 & 13.9 & 0.152 & 1.08 \\
\hline \multicolumn{6}{|l|}{ Promalin } \\
\hline 7) 25.0 & 200 & 64 & 13.9 & 0.179 & 1.06 \\
\hline \multicolumn{6}{|l|}{ Contrasts (significance) } \\
\hline Linear & $\mathrm{NS}^{\mathrm{y}}$ & * & NS & NS & NS \\
\hline Quadratic & NS & NS & NS & NS & * \\
\hline Cubic & NS & NS & NS & NS & NS \\
\hline Tl vs. T7 & $*$ & NS & * & NS & $*$ \\
\hline T3 vs. T6 & & NS & NS & NS & NS \\
\hline \multicolumn{6}{|c|}{ Full bloom +2 weeks } \\
\hline \multicolumn{6}{|c|}{ 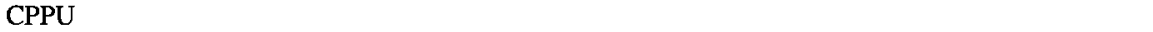 } \\
\hline $\begin{array}{l}\text { 1) } 0 \\
\text { 2) } 6.25\end{array}$ & 209 & 62 & 13.2 & 0.171 & 1.03 \\
\hline 2) 6.25 & 202 & 64 & 13.9 & 0.149 & 1.03 \\
\hline 3) 12.5 & 234 & 67 & 13.6 & 0.192 & 1.08 \\
\hline 4) 25.0 & 248 & 66 & 13.9 & 0.191 & 1.05 \\
\hline 5) 50.0 & 225 & 72 & 13.0 & 0.180 & 1.07 \\
\hline 6) $+\mathrm{GA}_{4+}$, both 12.5 & 246 & 65 & 13.4 & 0.175 & 1.09 \\
\hline \multicolumn{6}{|l|}{ Promalin } \\
\hline 7) 25.0 & 225 & 65 & 13.6 & 0.173 & 1.03 \\
\hline \multicolumn{6}{|l|}{ Contrasts (significance) } \\
\hline Linear & NS & * & NS & NS & NS \\
\hline Quadratic & NS & NS & NS & NS & NS \\
\hline Cubic & NS & NS & NS & NS & * \\
\hline Tl vs. $\mathrm{T} 7$ & NS & NS & NS & NS & NS \\
\hline T3 vs. T6 & NS & NS & NS & * & NS \\
\hline
\end{tabular}

${ }^{\mathrm{Z}} \mathrm{L} / \mathrm{D}=$ Length : diameter ratio.

'Mean of 120 observations.

Ns, Nonsignificant or significant at $P=0.05$. control, and flesh firmness at harvest linearly increased withincreasing concentrations. This increase was similar to that which occurred in trials in Washington (Table 2). Although Promalin increased L/D, it was not as effective as CPPU. Following storage, CPPU-treated fruit were firmer than nontreated controls (Table 3). Flesh firmness of Promalin-treated fruit was similar to that of control fruit at harvest and following storage (Tables 2 and 3 ). The only influence of treatment on storage disorders was a slight increase in scald caused by CPPU (Table 3). All CPPU concentrations

Effect of CPPU on 'Empire' apples in Massachusetts. CPPU applied to 'Empire' apples increased fruit weight linearly but did not affect fruit set, SSC, L/D, or firmness (data not shown). The only treatment that reduced return bloom in 1989 below the control's was the highest CPPU application rate-40 $\mathrm{mg} \cdot \mathrm{liter}^{-1}$; return bloom value for this CPPU application rate was $\approx 20 \%$ of the control's value.

Effect of CPPU on preharvest drop of 'Early McIntosh' in Massachusetts. Six days following treatment, CPPU applied at 100 $\mathrm{mg} \cdot \mathrm{liter}^{-1}$ and NAA applied at $20 \mathrm{mg} \cdot \operatorname{liter}^{-1}$ had reduced fruit drop of 'Early McIntosh' by $47 \%$ and $83 \%$, respectively, compared with the control (Table 4). After 14 days, however, the beneficialeffects of CPPU haddiminished, reduced return bloom in 1989. 
whereas NAA continued to retard fruit drop by $46 \%$. No treatment affected fruit drop during the next 16 days (data not shown).

Commercial grading of 'Hi-Early Delicious' treated with CPPU in Washington. There were $\approx 25$ bins ( $\approx 450 \mathrm{~kg}$ ) of fruit harvested from each treatment group. The percentage of fruit actually packed from each group was $85 \%$ for the control and Promalin treatments; $85 \%$ and $82 \%$, respectively, for CPPU at 5 and $10 \mathrm{mg} \cdot \mathrm{liter}^{-1}$ and $73 \%$ for CPPU at 15 mg.liter ${ }^{-1}$.

Reduced pack out at the highest CPPU concentrations was due mainly to an increase in malformed fruit frequency (Fig. 1). Fruit were classified as malformed if one side of the fruit was out of proportion or if the calyx end was uneven. Since cell division slows after anthesis, we believed that a higher concentration may be required at the later application time. However, the $15-\mathrm{mg} \cdot$ liter $^{-1}$ concentration was excessive. Even fruit treated with $10 \mathrm{mg} \cdot$ liter $^{-1}$ had $6 \%$ more deformed and misshapen fruit than the control.

CPPU treatments seemed to shift the mean fruit size to smaller fruit (Fig. 2). A Kolmogorov-Smirnov test, however, indicated no significant differences between any of the treatments and the control (data not shown). The control and Promalin treatments had the most fruit in the 80-, 88-, and >150-fruit/box sizes, whereas there were fewer fruit in the $>150-, 100-$, and 113-fruit/box sizes from the CPPU-treated trees. Results of blossom counts in 1990 indicated that none of the treatments influenced return bloom (data not shown).

CPPU seemed to increase the percentage of fruit surface that was red, since all CPPU treatments increased the percentage of Washington Extra Fancy fruit and reduced that of U.S. Fancy fruit (Fig. 3). Additionally, there were fewer culls due to poor color in the CPPU-treated fruit group (Fig. 1).

Fruit from air storage at $0 \mathrm{C}$ were evaluated in April after 7 days of storage at 20C. CPPU increased flesh firmness. Mean values for firmness were 53, 62, 62, and $62 \mathrm{~N}$, respec-

Table 2. Effect of CPPU applied at full bloom on fruit characteristics of spur 'Delicious'/MM.26 apples in Massachusetts.

\begin{tabular}{lcc}
\hline $\begin{array}{l}\text { Compound and } \\
\left.\text { concn (mg.liter }{ }^{-1}\right)\end{array}$ & L/D $^{z}$ & $\begin{array}{c}\text { Flesh } \\
\text { firmness } \\
(\mathrm{N})^{\mathrm{y}}\end{array}$ \\
\hline CPPU & 0.95 & 69 \\
1) 0 & 1.04 & 73 \\
2) 5 & 1.02 & 74 \\
3) 10 & 1.04 & 77 \\
4) 15 & 1.02 & 77 \\
5) 20 & 1.00 & 69 \\
Promalin & & \\
6) 25 & $*$ & $*$ \\
Contrasts (significance) & $*$ & NS \\
Linear & NS & NS \\
Quadratic & $*$ & NS \\
Cubic \\
Tl vs. T6 & $*$ & $*$ \\
T6 vs. T2 - T5 & \\
\hline
\end{tabular}

${ }^{\mathrm{z}}$ Mean of 180 observations; $\mathrm{L} / \mathrm{D}=$ length $:$ diameter ratio.

yean of 120 observations.

Ns, ${ }^{*}$ Nonsignificant or significant at $P=0.05$. tively, for the control and CPPU at 5, 10, and $15 \mathrm{mg} \cdot$ liter $^{-1}$, respectively.

Promalin is used commercially to elongate 'Delicious' apples. CPPU increased 'Delicious' $L / D$ in Washington similarly to Promalin, and, in Massachusetts, CPPU was superior to Promalin. Using CPPU at concentrations of up to $15 \mathrm{mg} \cdot$ liter $^{-1}$ may increase $\mathrm{L} /$ $\mathrm{D}$ the most. However, reduced return bloom (Table 3) and an unacceptably high incidence of malformed fruit at harvest when using these high application rates necessitates applying CPPU at rates below $10 \mathrm{mg} \cdot$ liter $^{-1}$.

CPPU increased 'Empire' fruit size. This response confirms reports that CPPU increased 'Mutsu' and 'Tsugaru' (Otaga et al., 1989), 'Granny Smith' (Nickel, 1986), and 'McIntosh' (Greene, 1989) apple fruit size. Fruit size is frequently increased commercially by reducing crop load using chemical or hand thinning. CPPU can thin (Greene, 1989), but in this investigation it increased fruit size in the absence of thinning. There was, however, a tendency toward decreased fruit set. Therefore, the increase in 'Empire' fruit size must be attributed directly to the chemical. CPPU thinned 'McIntosh', but it increased fruit size so much that Greene (1989) concluded that at least part of the increased fruit size must be attributed directly to CPPU. The lack of effect of CPPU on 'Delicious' fruit size in two experiments suggests that the effect of CPPU on increasing fruit size may depend on cultivar or weather.

Table 3. Effect of CPPU and Promalin applied in 1988 on fruit quality criteria following 28 weeks in air storage and on return bloom in 1989 of spur 'Delicious' apples in Massachusetts.

\begin{tabular}{|c|c|c|c|}
\hline $\begin{array}{l}\text { Compound and } \\
\text { concn (mg.liter-1) }\end{array}$ & $\begin{array}{c}\text { Flesh } \\
\text { firmness }^{2} \\
(\mathrm{~N})\end{array}$ & $\begin{array}{l}\text { Scald }^{y} \\
(\%)\end{array}$ & $\begin{array}{l}\text { Blossom clusters (1989)/ } \\
\mathrm{cm}^{2} \text { limb cross-section }\end{array}$ \\
\hline \multicolumn{4}{|l|}{ CPPU } \\
\hline 1) 0 & 46 & 0 & 12.0 \\
\hline 2) 5 & 50 & 2.0 & 5.7 \\
\hline 3) 10 & 52 & 3.7 & 1.8 \\
\hline 4) 15 & 53 & 3.4 & 2.1 \\
\hline 5) 20 & 54 & 6.8 & 5.6 \\
\hline \multicolumn{4}{|l|}{ Promalin } \\
\hline 6) 25 & 47 & 2.4 & 7.7 \\
\hline \multicolumn{4}{|c|}{ Contrasts (significance) } \\
\hline Linear & * & * & * \\
\hline Quadratic & * & NS & $*$ \\
\hline Cubic & NS & NS & NS \\
\hline Tl vs. T6 & NS & NS & NS \\
\hline T6 vs. T2 - T5 & * & NS & $*$ \\
\hline $\begin{array}{l}\text { Mean of } 120 \text { obse } \\
{ }^{\mathrm{y}} \text { Mean of six obser } \\
{ }^{\circ} \text { Mean of } 12 \text { obser } \\
\text { ss, }{ }^{\circ} \text { Nonsignificant }\end{array}$ & $=0.05$ & & \\
\hline
\end{tabular}

Table 4. Effect of CPPU or NAA applied on 2 Aug. on preharvest drops of 'Early McIntosh'.

\begin{tabular}{|c|c|c|c|c|}
\hline \multirow{2}{*}{$\begin{array}{l}\text { Compound and } \\
\left.\text { conen (mg.liter }{ }^{-1}\right)\end{array}$} & \multicolumn{4}{|c|}{ Fruit drop after days indicated ${ }^{z}$} \\
\hline & 3 & 8 & 11 & 14 \\
\hline Control & $23.0 \mathrm{a}^{y}$ & $37.1 \mathrm{a}$ & $39.1 \mathbf{a}$ & $\overline{56.0 \mathrm{a}}$ \\
\hline \multicolumn{5}{|l|}{ CPPU } \\
\hline 50 & $14.1 \mathrm{a}$ & $32.2 \mathrm{a}$ & $46.1 \mathrm{a}$ & $58.6 \mathrm{a}$ \\
\hline 100 & $9.5 \mathrm{~b}$ & $19.6 \mathrm{bc}$ & $37.1 \mathrm{a}$ & $52.3 \mathrm{a}$ \\
\hline \multicolumn{5}{|l|}{ NAA } \\
\hline 20 & $3.4 \mathrm{~b}$ & $6.2 \mathrm{c}$ & $15.4 \mathrm{~b}$ & $30.3 \mathrm{~b}$ \\
\hline
\end{tabular}

${ }^{\mathrm{z}}$ Mean of seven observations.

y'Mean separation by Duncan's multiple range test, $P=0.05$.
CPPU seemed to increase red pigmentation in the commercial field trial. Sansavini (1990, personal communication) reported a CPPU was applied at $20 \mathrm{mg} \cdot$ liter $^{-1} 25$ days after FB. However, Devlin and Koszanski (1988) found that anthocyanin and flavinol pigments in cranberry (Vaccinium macrocappon Ait.) decreased following CPPU treatment, and Greene (1989) reported that red pigmentation (ncestosh' apples receiving CPPU at $100 \mathrm{mg} \cdot$ liter $^{-1}$ but not $10 \mathrm{mg} \cdot$ liter $^{-1}$. CPPU's effect on color may deenvironmental conditions.

Regardless of application time, CPPU increased 'Delicious' flesh firmness. This response confirms a previous report in which (Greene, 1989). Oclntosh' flesh firmness butanedioic acid mono-(2,2-dimethylhydrazide (daminozide) (Greene et al., 1977) and BA (Greene and Autio, 1989), increase flesh frest. However, unlike fruit flesh firmness increases caused by CPPU did not dissipate, but persisted after storage.

Greene (1989) observed at harvest that fruit treated with CPPU were difficult to separate from the spur. He suggested that CPPU prevent preharvest drop. CPPU retarded 'Early McIntosh' apple preharvest drop in this investigation, although it was not as effective as NAA-a chemical used commercially to 


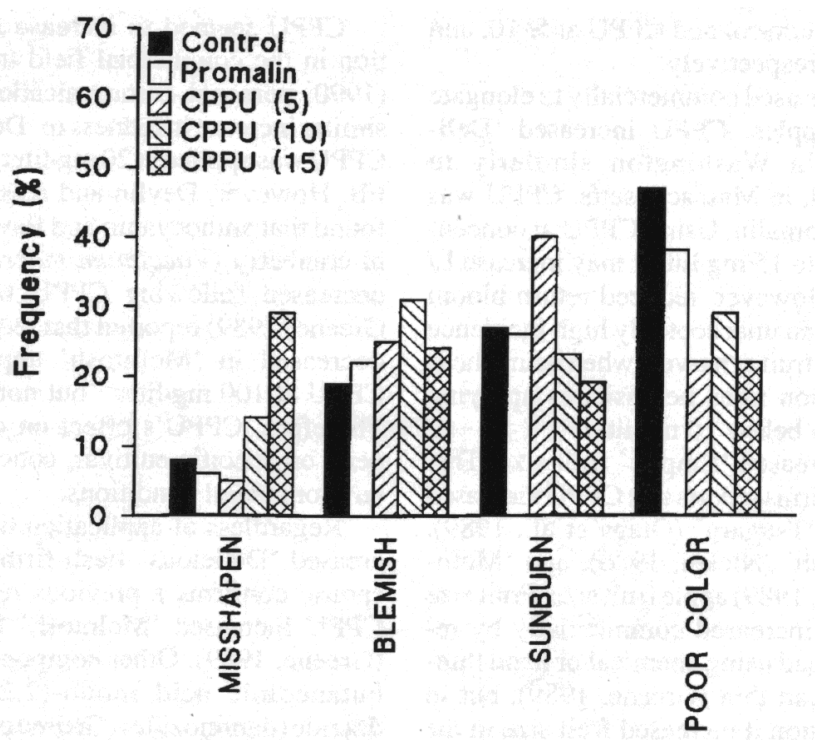

Fig. 1. Cull analysis of fruit from 20-year-old 'Hi-Early'/seedling trees treated with CPPU at 5, 10, or 15 $\mathrm{mg} \cdot \mathrm{liter}^{-1}$ or Promalin at $25 \mathrm{mg} \cdot$ liter $^{-1}$.

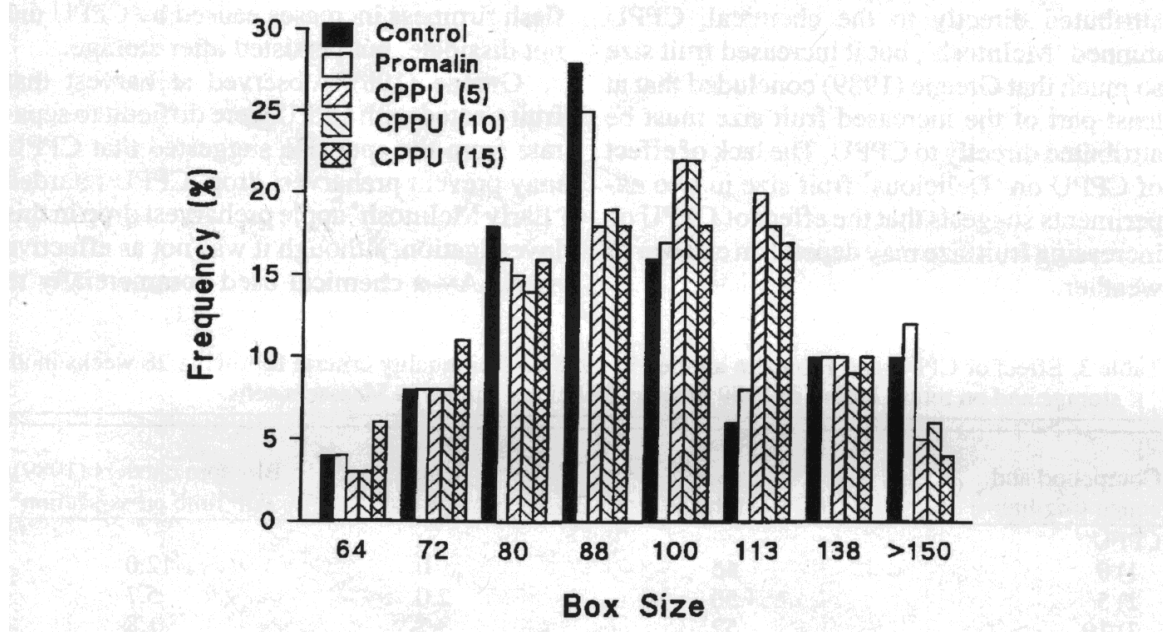

Fig. 2. Size distribution of fruit from 20-year-old 'Hi-Early'/seedling trees treated with CPPU at 5,10, or $15 \mathrm{mg} \cdot \mathrm{liter}^{-1}$ or Promalin at $25 \mathrm{mg} \cdot \mathrm{liter}^{-1}$. Box size indicates the number of fruit in an 18-kg container.

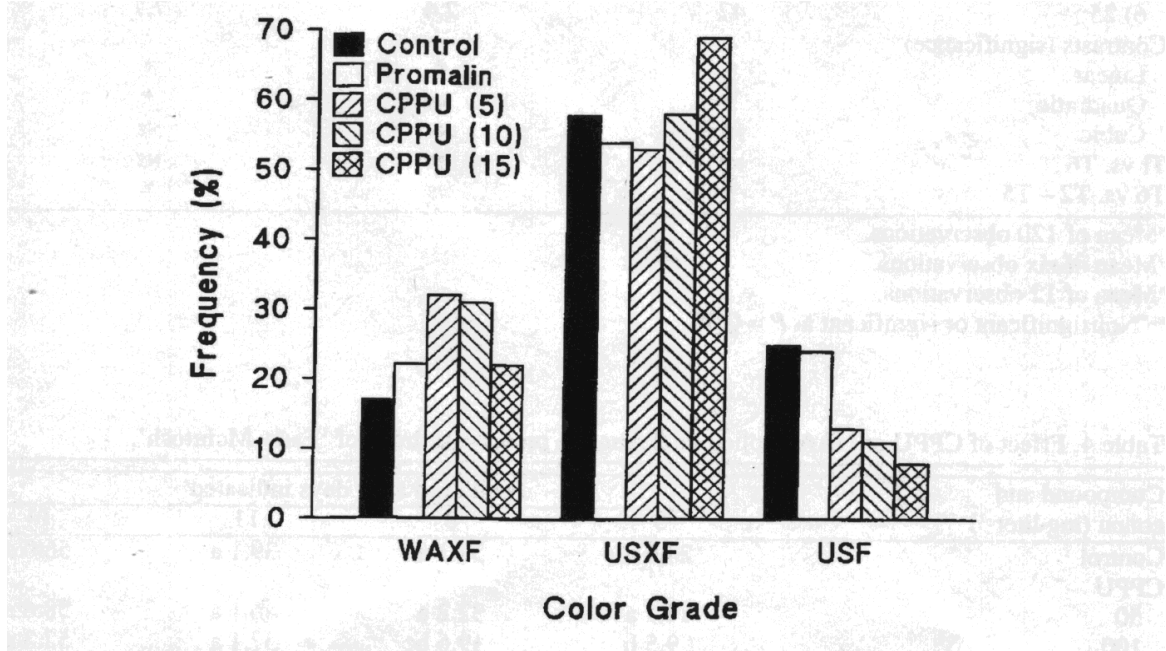

Fig. 3. Color grade of fruit from 20-year-old 'High-Early'Peedling trees treated with CPPU at 5,10, or 15 $\mathrm{mg} \cdot \mathrm{lite}^{-1}$ or Promalin at $25 \mathrm{mg} \cdot$ liter $^{-1}$. Requirements for percent surface pigmentation are as follows: Washington Extra Fancy (WAXF), 66\% deep red; U.S. Extra Fancy (USXF), 66\% deep red or pink-red; and U.S. Fancy, $40 \%$ deep red or pink-red. retard preharvest drop-should be. More frequently, cytokinins increase rather than retard abscission. BA promotes abscission of developing apple fruit (Greene and Autio, 1989; McLaughlin and Greene, 1984). $N$-phenyl- $N^{\prime}$ 1,2,3-thiadiazol-5-ylurea (thidiazuron), a phenylurea similar to CPPU that has cytokinin activity, promotes leaf abscission in cotton (Gosypium hirsutum L.) (Suttle, 1985).

Luckwill (1969) first suggested that cytokinins may stimulate flower bud formation in fruit spurs. The cytolcinins that have been reported to increase flower bud formation are $\mathrm{N}^{6}$-substituted purines and not phenylurea compounds like CPPU. Greene and Autio (1989), Greene et al. (1990), and McLaughlin and Greene (1984) have confirmed that BA increases flower bud formation in apples. In this study, CPPU inhibited 'Empire' flower bud formation. This result confirms an earlier report that CPPU also inhibited 'McIntosh' return bloom (Greene, 1989).

\section{Literature Cited}

Bruce, MI., J.A. Zwar, and N.P. Kefford. 1965. Chemical structure and plant kinin activity. The activity of urea and thiourea derivatives. Life Sci. 4:461-466.

Curry, E.A. and M.W. Williams. 1987. Enhancing typiness of 'Delicious' apples with substituted phenylureas. HortScience 22:167.

Devlin, R.M. and Z.K. Koszanski. 1988. Effect of CPPU on yield and developmentof 'Early Black' cranberry. Proc. Plant Growth Regulat. Soc. Amer. 15:136-140.

Greene, D.W. 1989. CPPU influences 'McIntosh' apple crop load and fruit characteristics. HortScience 24:94-96.

Greene, D.W. and W.R. Autio. 1989. Evaluation of benzyladenine as a chemical thinner on 'McIntosh' apples. J. Amer. Soc. Hort. Sci. 114:6873.

Greene, D.W., W.R. Autio, and P. Miller. 1990. Thinning activity of benzyladenine on several applecultivars. J. Amer. Soc. Hort. Sci. 115:394400.

Greene, D.W. and E.A. Curry. 1989. Effect of CPPU on fruit set, fruit characteristics and preharvest drop of apples. HortScience 24:223. Greene, D.W., W.J. Lord, and W.J. Bramlage. 1977. Mid-summer applications of ethephon and daminozide on apples. II. Effect on 'Delicious'. J. Amer. Soc. Hort. Sci. 102:494-497.

Kurosaki, F., S. Takahashi, K. Shudo, T. Okamoto, and Y. Isogai. 1981. Structural and biological links between urea- and purine-cytokinins. Chem. Pharmaceutical Bul. (Tokyo) 29:37513753.

Luckwill, L.C. 1969. The control of growth and fruitfulness of apple trees, p. 123-153. In: L.C. Luckwill and C.V. Cutting (eds.). Physiology of tree crops. Academic, New York.

Martin, G.C.,D.S. Brown, and N.M. Nelson. 1970. Apple shape changing possible with cytokinin and gibberellin sprays. Calif. Agr. 24:14.

McLaughlin, J.M. and D.W. Greene. 1984. Effects of BA, $\mathrm{GA}_{4+7}$, and daminozide on fruit set, fruit quality, vegetative growth, flower initiation, and flower quality of 'Golden Delicious' apple. J. Amer. Soc. Hort. Sci. 109:34-39.

Nickell, L.G. 1985. New plant growth regulator increases grape size. Proc. Plant Growth Regulat. Soc. Amer. 12:1-7.

Nickell, L.G. 1986. Effects of N-(2-chloro-4pyridyl)N'-phenylurea on grapes and other crops. 
Proc. Plant Growth Regulat. Soc. Amer. 13:236241.

Ogata, R., T. Saito, and K. Oshima. 1989. Effect of N-phenly-n'-(4.pyridyl)urea(4-PU)on fruit size of apple, Japanese pear, grape and kiwifruit. Acta Hort. 239:395-398.

Okamoto,T., K. Shudo, S. Takahashi, E. Kawachi, and Y. Isogai. 1981. 4-Pyridylureas are surprisingly potent cytokinins. The structureactivity relationship. Chem. Pharmaceutical
Bul. (Tokyo) 29:3748-3750.

SAS Institute. 1985. SAS user's guide: Statistics. version 5. SAS Institute, Cary, N.C.

Shantz, E.M. and F. C. Steward. 1955. The identification of compound A from coconut milk as 1,3diphenylurea. J. Amer. Chem. Soc. 77:6351.

Suttle, J.C. 1985. Involvement of ethylene in the action of the cotton defoliant thidiazuron. Plant Physiol. 78:272-276.

Takahashi, S., K. Shudo, T. Okamoto, K. Yamada, and Y. Isogai. 1978. Cytokinin activity of Nphenyl-N'-(4-pyridyl) urea derivatives. Phytochemistry 17:1201-1207.

Thomas, J.C. and F.R. Katterman. 1986. Cytokinin activity induced by thidiazuron. Plant Physiol. 81:681-683.

Williams, M.W. and E.A. Stahly. 1969. Effect of cytokinins and gibberellins on shape of 'Delicious' apple fruits. J. Amer. Soc. Hort. Sci. 94:17-19. 